\title{
PENGARUH KINERJA KEUANGAN DAN CORPORATE SOCIAI RESPONSIBILITY (CSR) TERHADAP NILAI PERUSAHAAN MANUFAKTUR YANG TERDAFTAR DI BURSA EFEK INDONESIA
}

\author{
Angelika Natalia Joseph \\ Agus T. Poputra \\ Victorina Z. Tirayoh \\ Fakultas Ekonomi dan Bisnis Jurusan Akuntansi \\ Universitas Sam Ratulangi \\ Email: angelikajoseph489@yahoo.co.id
}

\begin{abstract}
The financial performance is an image of a quality company that is reflected through the financial performance in a given period. Corporate Social Responsibility (CSR) is the ability of the company to connect its operations and policies of the social environment in a way that is mutually beneficial for the company and the community. The company's value is the market value as the value of the company can deliver maximum shareholder wealth when the company's stock price to rise. The purpose of this study was to analyze the influence of corporate social responsibility (CSR), and the financial performance of the company's value. Object Manufacturing research company that totaled 143 company, but based on the completeness of data then only 18 companies into the sample with the observation period 2012 - 2015. The independent variables were the company's performance (return on assets, return on equity, Operating Profit Margin, Net Profit Margin) and Corporate Responsibility Cocial, while the enterprise value of the dependent variable (Price Book value). Analysis of the data used consisted of correlation analysis, determination analysis, $t$-test, $f$, and multiple linear regression analysis. The results of this study indicate that ROA and ROE have a significant influence on the value of the company, while OPM, NPM, and CSR does not have a significant influence on the value of the company. F test analysis results indicate that the independent variables namely financial performance and CSR affect the value of the company.
\end{abstract}

Keywords : corporate value, corporate social responsibility, corporate performance

\section{Latar Belakang}

\section{Pendahuluan}

Pada era globalisasi ini, kondisi perekonomian terus mengalami perkembangan, yang ditunjukkan dengan semakin banyaknya perusahaan-perusahaan yang berdiri saat ini baik itu yang berskala kecil maupun besar. Dengan banyaknya perusahaan yang ada tentu akan menimbulkan suatu persaingan bisnis yang makin ketat antar perusahaan.

Tujuan lain dari didirikannya suatu perusahaan adalah untuk memaksimalkan nilai perusahaan. Nilai perusahaan menggambarkan seberapa baik atau buruk manajemen mengelola kekayaannya, hal ini bisa dilihat dari pengukuran kinerja keuangan yang diperoleh. Suatu perusahaan akan berusaha untuk memaksimalkan nilai perusahaannya. Peningkatan nilai perusahaan biasanya ditandai dengan naiknya harga saham di pasar (Rahayu, 2010). Setiap perusahaan tentunya menginginkan nilai perusahaan yang tinggi sebab hal tersebut juga secara tidak langsung menunjukkan kemakmuran pemegang saham juga tinggi. Nilai perusahaan yang tinggi dapat meningkatkan kemakmuran bagi para pemegang saham, sehingga para pemegang saham akan menginvestasikan modalnya kepada perusahaan tersebut (Haruman, 2008).

Menurut Zuredah (2010), pengukuran kinerja keuangan merupakan salah satu faktor yang sangat penting dalam perusahaan, karena pengukuran tersebut digunakan sebagai dasar untuk menyusun sistem imbalan dalam perusahaan, yang dapat mempengaruhi perilaku pengambilan keputusan dalam perusahaan dan memberikan informasi yang berguna dalam membuat keputusan yang penting mengenai aset yang digunakan untuk membuat keputusan yang menyalurkan kepentingan perusahaan. 
Untuk mengukur kinerja keuangan perusahaan biasanya menggunakan analisis rasio keuangan. Rasio-rasio itu antara lain Return On Asset (ROA), Return On Equity (ROE), Operating Profit Margin (OPM), dan Net Profit Margin (NPM) merupakan contoh indikator yang lazim atau sering digunakan oleh para peneliti untuk menilai tingkat profitabilitas perusahaan. Penilaian prestasi suatu perusahaan dapat dilihat dari kemampuan perusahaan itu menghasilkan laba. Laba perusahaan selain merupakan indikator kemampuan perusahaan memenuhi kewajiban bagi para penyandang dananya juga merupakan elemen dalam penciptaan nilai perusahaan yang menunjukkan prospek perusahaan di masa yang akan datang (Rahayu, 2010).

Pada saat ini banyak perusahaan menjadi semakin berkembang, maka pada saat itu pula kesenjangan sosial dan kerusakan lingkungan sekitarnya dapat terjadi. Saat ini telah muncul kesadaran untuk mengurangi dampak negatif dari Perusahaan. Oleh sebab itu banyak perusahaan besar telah mengembangkan apa yang disebut Corporate Social Responsibilty (CSR). Penerapan CSR tidak lagi dianggap sebagai cost, melainkan investasi perusahaan (Erni, 2007). Oleh sebab itu, tanggung jawab sosial perusahaan atau yang lebih dikenal dengan CSR sebenarnya telah menjadi perbincangan beberapa dekade lalu, dan kini juga tengah marak gaungnya ditingkat nasional maupun global. Telah banyak perusahaan yang menyatakan bahwa CSR adalah penting karena perusahaan tidak hanya memiliki tanggung jawab ekonomis kepada para shareholders mengenai bagaimana memperoleh profit yang besar, namun perusahaan juga harus memliki sisi tanggung jawab sosial terhadap stakeholders dilingkungan tempat perusahaan beroperasi (Handoko, 2010).

\section{Tujuan Penelitian}

Penelitian ini bertujuan untuk mengetahui pengaruh:

1. Kinerja keuangan terhadap nilai perusahaan Manufaktur yang terdaftar di Bursa Efek Indonesia.

2. Corporate Social Responsibility (CSR) terhadap nilai perusahaan Manufaktur yang terdaftar di Bursa Efek Indonesia.

3. Kinerja keuangan dan Corporate Social Responsibility (CSR) secara keseluruhan terhadap nilai perusahaan Manufaktur yang terdaftar di Bursa Efek Indonesia

\section{Nilai Perusahaan}

\section{TINJAUAN PUSTAKA}

Nilai perusahaan merupakan persepsi investor terhadap perusahaan, yang sering dikaitkan dengan harga saham. Harga saham yang tinggi membuat nilai perusahaan juga tinggi. Tujuan utama perusahaan menurut theory of the firm adalah untuk memaksimumkan kekayaan atau nilai perusahaan (value of the firm) (Salvatore, 2005:154). Untuk mencapai nilai perusahaan umumnya para pemodal menyerahkan pengelolaannya kepada para professional. Para professional diposisikan sebagai manajer ataupun komisaris (Nurlela dan Islahuddin, 2008).

\section{Teori Stakeholder}

Menurut Ghazali dan Chariri (2007:409), Teori Stakeholder merupakan teori yang menyatakan bahwa perusahaan bukanlah entitas yang hanya beroperasi untuk kepentingan sendiri, namun harus memberikan manfaat kepada seluruh stakeholder-nya (pemegang saham, kreditor, konsumen, supplier, pemerintah, masyarakat, analis, dan pihak lain).

\section{Kinerja Keuangan}

Munawir (2010), kinerja keuangan merupakan satu diantara dasar penilaian mengenai kondisi keuangan perusahaan yang dilakukan berdasarkan analisa terhadap rasio keuangan perusahaan. Dari uraian definisi-definisi tersebut dapat dikatakan bahwa kinerja keuangan adalah gambaran suatu kualitas perusahaan yang tercermin melalui pelaksanaan keuangan pada suatu periode tertentu. 


\section{Rasio Keuangan}

Menurut Sutrisno (2008) mengatakan analisis rasio keuangan adalah menghubungkan elemenelemen yang ada dilaporan keuangan. Sedangkan menurut Kasmir (2010), rasio keuangan adalah alat yang digunakan untuk menganalisis kondisi keuangan dan kinerja perusahaan.

\section{Return on Assets (ROA)}

Analisis Return On Assets atau sering diterjemahkan dalam bahasa Indonesia sebagai rentabilitas ekonomi mengukur perkembangan perusahaan menghasilkan laba pada masa lalu. Analisis ini kemudian diproyeksikan ke masa mendatang untuk melihat kemampuan perusahaan menghasilkan laba pada masamasa mendatang. Rasio ini dapat dirumuskan sebagai berikut.

$$
\text { ROA }=\frac{\text { Laba Bersih }}{\text { Total Aktiva }} \quad \times \quad 100 \%
$$

\section{Return on Equity (ROE)}

Menurut Brigham (2006) para pemegang saham melakukan investasi untuk mendapatkan pengembalian atas uang mereka, dan rasio ini menunjukkan seberapa baik mereka telah melakukan hal tersebut dari kacamata akuntansi. Angka ROE dapat dikatakan baik apabila $>12 \%$. Secara sistematis dapat dirumuskan sebagai berikut.

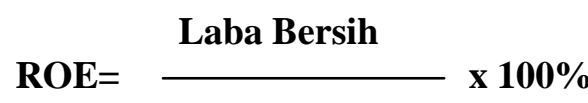 \\ Modal Sendiri}

\section{Operating Profit Margin (OPM)}

Operating Profit Margin Adalah untuk mengukur kemampuan perusahaan dalam menghasilkan keuntungan. Operating profit margin mengukur persentase dari profit yang diperoleh perusahaan dari tiap penjualan sebelum dikurangi dengan biaya bunga dan pajak.. Secara sistematis dapat dirumuskan sebagai berikut.

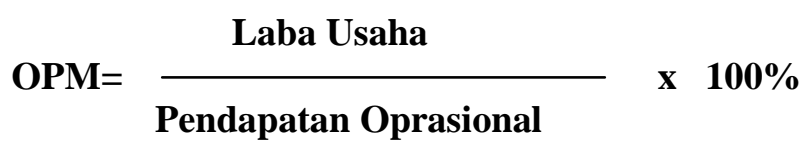

\section{Net Profit Margin (NPM)}

Net profit margin mengukur persentase dari setiap penjualan dollar yang tersisa setelah semua biaya dan pengeluaran, termasuk bunga, pajak dan dividen saham preferen, telah dikurangi. Rasio yang digunakan untuk menunjukkan kemampuan perusahaan dalam menghasilkan keuntungan bersih setelah dipotong pajak menurut Gitman (2012:80). Secara sistematis dapat dirumuskan sebagai berikut.

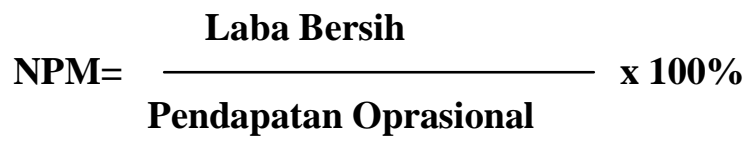

Corporate Social Responsibility (CSR) 
Corporate social responsibility (CSR) atau pertanggung-jawaban sosial perusahaan adalah mekanisme bagi suatu organisasi untuk secara sukarela mengintegrasikan perhatian terhadap lingkungan dan sosial ke dalam operasinya dan interaksinya dengan stakeholders, yang melebihi tanggung jawab organisasi di bidang hukum. Corporate social responsibility merupakan komitmen perusahaan atau dunia bisnis untuk dalam Item yang diungkapkan oleh perusahaan

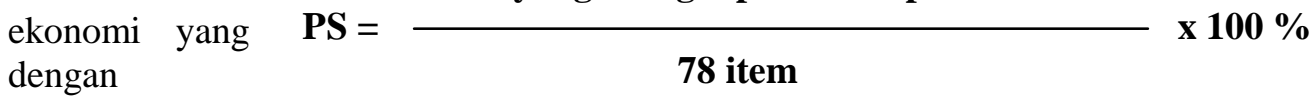
kontribusi pembangunan berkelanjutan

menitikberatkan pada keseimbangan antara perhatian terhadap aspek ekonomi, sosial, dan lingkungan.

\section{Penelitian Terdahulu}

Chairul Amri (2011) melakukan penelitian dengan judul Analisis Pengaruh Kinerja Keuangan, Good Corporate Governance Dan Corporate Social Responsibility Terhadap Nilai Perusahaan. Penelitian ini bertujuan untuk mengetahui pengaruh Kinerja Keuangan, Good Corporate Governance Dan Corporate Social Responsibility Terhadap Nilai Perusahaan. Pengumpulan data menggunakan metode purposive sampling terhadap perusahaan yang termasuk dalam kategori LQ45 yang terdaftar di Bursa Efek Indonesia. Pada penelitian ini variabel independennya adalah kinerja keuangan, Corporate Social Responsibility, dan sebagai variabel dependennya adalah nilai perusahaan yang dihitung menggunakan Tobin's Q. Hasil penelitian menunjukkan bahwa variabel-variabel yang di uji berpengaruh secara signifikan terhadap nilai perusahaan.

Angra Hermawati (2010) melakukan penelitian dengan judul Pengaruh Kinerja Keuangan Terhadap Nilai Perusahaan Dengan Pengungkapan Corporate Social Responsibility Dan Struktur Kepemilikan Sebagai Variabel Pemoderasi. Penelitian ini dilakukan dengan tujuan untuk mengetahui atau menganalisa pengaruh kinerja keuangan terhadap nilai perusahaan. Nilai perusahaan dalam penelitian ini diproksi dengan nilai Price Book Value. Pengumpulan data menggunakan metode purposive sampling terhadap perusahaan yang termasuk dalam kategori perusahaan industry manufaktur yang terdaftar di BEI periode 2007-2009. Pada penelitian ini variabel independennya adalah kinerja keuangan yang diproksikan dengan Return on Asset (ROA) dan Return on Equity (ROE). Variabel pemoderasi adalah Corporate Social Responsibility dan struktur kepemilikan. Sedangkan untuk variabel dependennya adalah nilai perusahaan yang dihitung menggunakan Price Book Value. Adapun hasil dari penelitian adalah menunjukan bahwa variabel independen yang diuji berpengaruh secara signifikan terhadap nilai perusahaan pada perusahaan manufaktur di BEI. Sedangkan untuk variabel pemoderasi Corporate Social Responsibility adalah bukan merupakan variabel moderating terhadap hubungan ROA, ROE, dan PBV, dan untuk struktur kepemilikan berpengaruh signifikan negatif terhadap hubungan ROA, ROE, dan PBV.

\section{Jenis Penelitian}

\section{METODE PENELITIAN}

Berdasarkan tingkat eksplanasinya (tingkat penjelasan) penelitian ini termasuk dalam penelitian asosiatif kausal (causal assosiative). 


\section{Tempat Penelitian}

Dalam penelitian ini, penulis memilih lokasi di Pojok Bursa Efek Fakultas Ekonomi dan Bisnis Universitas Sam Ratulangi sebagai tempat penelitian.

\section{Populasi dan Sampel}

Populasi memiliki pengertian sebagai seluruh kumpulan elemen yang menunjukkan ciri-ciri tertentu yang dapat digunakan untuk membuat kesimpulan. Populasi yang digunakan dalam penelitian ini adalah perusahaan Manufaktur yang terdaftar di Bursa Efek Indonesia dari Tahun 2012 sampai dengan 2015 yaitu sebanyak 143 perusahaan. Menurut Sugiyono (2005:119), sampel adalah bagian dari jumlah dan karakteristik yang dimilki oleh populasi tersebut. Berdasarkan kriteria sampel maka sampel dalam penelitian ini sebanyak 18 perusahaan.

\section{Metode Pengumpulan Data}

Dalam penelitian ini, digunakan data kuantitatif berupa Laporan Keuangan Tahunan Perusahaan Manufaktur Yang Terdaftar di BEI Periode 2012-2015. Sumber data yang digunakan penulis dalam penyusunan penelitian ini adalah data sekunder berupa laporan keuangan tahunan Perusahaan Manufaktur Yang Terdaftar di BEI Periode 2012-2015.

\section{Metode Analisis Data Uji Statistik Deskriptif}

Statistik deskriptif digunakan untuk menggambarkan profil data sampel yang meliputi antara lain maksimum, minimum, mean (rata-rata) dan data standar deviasi. Data yang telah diteliti dikelompokkan menjadi enam, yaitu return on assets, return on equity, operating profit margin, net profit margin, corporate social responsibility, dan nilai perusahaan.

\section{Pengujian Asumsi Klasik}

Pengujian asumsi klasik bertujuan untuk mengetahui dan meguji kelayakan atas model regresi yang digunakan untuk penelitian ini. Pengujian ini juga dimaksudkan untuk memastikan bahwa di dalam model regresi yang digunakan tidak terdapat autokorelasi, multikolineritas, dan heteroskedastisitas serta untuk memastikan bahwa data yang dhasilkan berdistribusi normal (Ghozali, 2006).

\section{Uji Normalitas}

Uji normalitas bertujuan untuk menguji apakah dalam model regresi, variabel pengganggu atau residual memiliki distribusi normal (Ghozali, 2006). Ada dua cara untuk mengetahui apakah residual terdistribusi normal atau tidak yaitu dengan analisis grafik dan uji statistik. Karena analisis grafik dapat menyesatkan, maka dipilih uji statistik Kolmogorov-Smirnov dengan melihat tingkat signifikansinya.

\section{Uji Multikolineritas}

Uji multikolinearitas bertujuan untuk menguji apakah dalam model regresi ditemukan adanya korelasi antar variabel bebas dalam model regresi (Ghozali, 2006). Model regresi yang baik seharusnya bebas dari multikolineritas. Deteksi terhadap ada tidaknya multikolineritas yaitu (a) Nilai R square (R2) yang dihasilkan oleh suatu estimasi model regresi empiris yang sangat tinggi, tetapi secara individual tidak terikat, (b) Menganalisis matrik variabel-variebel independen.

\section{Uji Heteroskedastisitas}

Uji Heteroskedastisitas bertujuan menguji apakah dalam model regresi terjadi ketidaksamaan variance dari residual satu pengamatan ke pengamatan yang lain. Jika variance dan residual satu pengamatan ke pengamatan lain tetap, maka disebut Homoskedasitisitas dan jika berbeda disebut Heteroskedastisitas. Model regresi yang baik adalah yang Homoskesdatisitas atau tidak terjadi Heteroskedastisitas 


\section{Uji Autokorelasi}

Uji autokorelasi bertujuan untuk menguji apakah dalam model regresi linier berganda ada korelasi antara kesalahan penggangu pada periode $t$ dengan kesalahan penganggu pada pada periode $t-1$ (sebelumnya). (Ghozali, 2006). Autokorelasi timbul karena observasi yang berurutan sepanjang waktu berkaitan satu sama lainnya.

\section{Analisis Data}

\section{HASIL PENELITIAN DAN PEMBAHASAN}

\subsubsection{Uji Statistik Deskriptif}

Tabel 4.2

Hasil Uji Statistik Deskriptif Descriptive Statistics

\begin{tabular}{cccccc}
\hline & N & Minimum & Maximum & Mean & Std. Deviation \\
\hline PBV & 72 & .03 & 284.00 & 34.8131 & 60.85392 \\
ROA & 72 & -4.39 & 84.49 & 20.0893 & 23.26042 \\
ROE & 72 & -5.92 & 260.58 & 22.4058 & 34.88593 \\
OPM & 72 & 3.80 & 14.56 & 10.0146 & 2.90828 \\
NPM & 72 & .07 & 54.30 & 15.9406 & 16.33096 \\
CSR & 72 & 3.84 & 56.40 & 19.8128 & 13.21875 \\
\hline Valid N (listwise) & 72 & & & &
\end{tabular}

Valid N (listwise) 72

Sumber: Data sekunder diolah melalui SPSS 16, 2016

Pada bagian ini akan digambarkan atau dideskripsikan data informasi mengenai variabel-variabel penelitian seperti nilai perusahaan (PBV), Return On Assets, Return On Equity, Operating Profit Margin, Net Profit Margin dan Corporate Social Responsibility pada tahun 2012 sampai dengan 2015 yang dilihat dari nilai minimum, nilai maksimum, nilai rata-rata (mean) dan standar deviasi dari masing-masing variabel

\section{Uji Normalitas}

Tabel 4.3

Hasil Uji Normalitas

One-Sample Kolmogorov-Smirnov Test

\begin{tabular}{llr} 
& & $\begin{array}{r}\text { Unstandardiz } \\
\text { ed Residual }\end{array}$ \\
\hline $\mathrm{N}$ & & 72 \\
Normal Parameters & & Mean \\
& Std. Deviation & .0000000 \\
Most Extreme & Absolute & 53.03098576 \\
Differences & Positive & .172 \\
& Negative & .172 \\
Kolmogorov-Smirnov Z & -.113 \\
Asymp. Sig. (2-tailed) & & 1.456 \\
\end{tabular}


Sumber: Data sekunder diolah melalui SPSS 16, 2016.

Hasil uji Kolmogorov-Smirnov pada tabel 4.3 menunjukkan nilai Kolmogorov Smirnov sebesar 1.456 dengan nilai probabilitas signifikan (Asymp. Sig) sebesar 0.129. karena nilai p atau Asymp. Sig > 0.05, maka dapat disimpulkan bahwa data residual terdistribusi secara normal. Dengan kata lain, model regresi penelitian ini terdistribusi normal

\section{Uji Multikolineritas}

\section{Tabel 4.4}

Hasil Uji Multikolineritas

\begin{tabular}{llrr} 
& & \multicolumn{2}{c}{ Collinearity Statistics } \\
\cline { 3 - 4 } Model & & Tolerance & \multicolumn{1}{l}{ VIF } \\
\hline 1 & ROA & .601 & 1.663 \\
& ROE & .629 & 1.590 \\
& OPM & .838 & 1.193 \\
& NPM & .949 & 1.054 \\
& CSR & .864 & 1.157 \\
\hline
\end{tabular}

a. Dependent Variable: PBV

Sumber: Data sekunder diolah melalui SPSS 16, 2016.

Berdasarkan hasil uji pada tabel 4.4 terlihat bahwa menunjukan semua nilai VIF dari semua variabel independen dalam penelitian ini mempunyai nilai VIF $<10$. Maka dapat dikatakan berarti data terbebas dari multikolineritas.

\section{Uji Heteroskedastisitas}

Uji heteroskedastisitas bertujuan untuk menguji apakah dalam model regresi terjadi ketidaksamaan variance dari residual satu ke pengamatan yang lain. Jika variance dan residual satu pengamatan ke pengamatan lain tetap, maka disebut Homoskedastisitas dan jika berbeda disebut Heteroskedastisitas. Cara untuk mendeteksi ada atau tidaknya heteroskedastisitas yaitu dengan melihat grafik scatter plot antara nilai prediksi variabel terikat (dependen) yaitu ZPRED dengan residualnya SRESID. Hasil analisis dapat dilihat pada gambar 4.1.

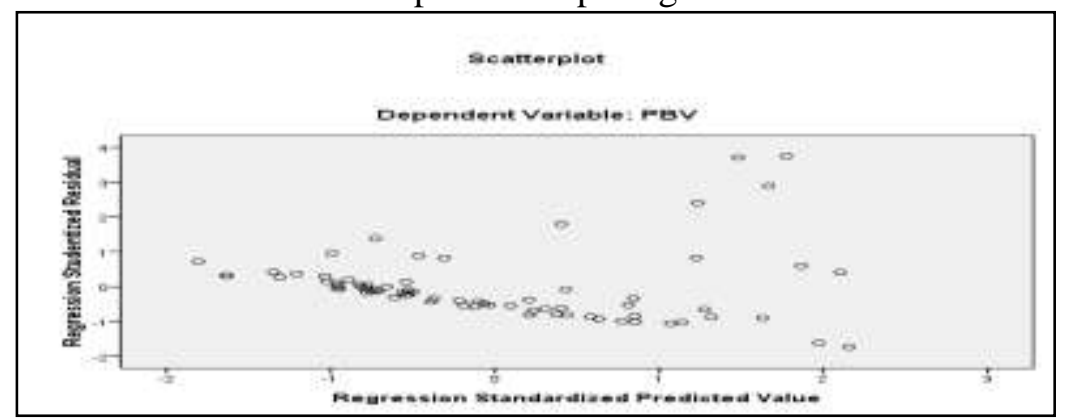

Gambar 4.1

\section{Hasil Uji Heteroskedastisitas}

Berdasarkan hasil dari scatter plot pada tabel 4.1 terlihat bahwa plot yang terbentuk tidak memiliki pola yang jelas, serta titik-titik menyebar di atas dan dibawah angka 0 pada sumbu Y, maka dapat dikatakan tidak terjadi heteroskedastisitas. 


Masil Uji Autokorelasi
Model Summary
Model

Berdasarkan hasil output pada tabel 4.5 didapat nilai DW sebesar 846, nilai ini akan dibandingkan dengan nilai tabel dengan menggunakan nilai signifikansi sebesar 5\% atau 0,05. Untuk jumlah data $\mathrm{n}=$ 72, maka nilai dL sebesar 0.0832 dan dU sebesar 1,2845. Karena nilai DW $846>0.0832$ dan berada dibawah < 4-dU $(4-1,7675=2.6453)$. Maka dapat disimpulkan bahwa tidak terdapat autokorelasi pada penelitian ini.

\section{Pembahasan \\ Pengaruh Return On Assets (ROA) terhadap Nilai Perusahaan}

Hasil pengujian mengenai pengaruh return on assets terhadap nilai perusahaan menunjukkan nilai t sebesar 1,317 dengan signifikansi sebesar 0,192. Hal tersebut menandakan bahwa variabel return on assets memiliki pengaruh yang signifikan terhadap nilai perusahaan. Hasil ini mendukung penelitian sebelumnya yang sudah dilakukan oleh Ulupi (2007) yang menyatakan bahwa nilai perusahaan ditentukan oleh earning power dari aset perusahaan. Hasil yang positif menunjukkan bahwa semakin tinggi earning power maka semakin efisien perputaran asset dan atau semakin tinggi profit margin yang diperoleh oleh perusahaan. Hal ini berdampak pada peningkatan nilai perusahaan dalam hal ini return saham satu tahun kedepan.

\section{Pengaruh Return On Equity (ROE) terhadap Nilai Perusahaan}

Salah satu perusahaan beroperasi adalah menghasilkan laba yang bermanfaat bagi para pemegang saham. Ukuran dari keberhasilan pencapaian alasan ini adalah angka ROE yang berhasil dicapai. Semakin besar ROE mencerminkan kemampuan perusahaan dalam menghasilkan keuntungan yang tinggi bagi para pemegang saham. Hal ini berdampak terhadap peningkatan nilai perusahaan. Hasil pengujian pengaruh ROE terhadap nilai perusahaan menunjukkan hasil nilai t sebesar 0.568 dengan signifikansi sebesar 0,572. Nilai t hitung yang lebih kecil dari t tabel 2,00030 tersebut menandakan bahwa variabel return on equity berpengaruh secara signifikan terhadap nilai perusahaan.

\section{Pengaruh Operating Profit Margin (OPM) terhadap Nilai Perusahaan}

Hasil pengujian mengenai pengaruh OPM terhadap nilai perusahaan menunjukkan nilai t sebesar -2.570 dengan signifikansi sebesar 0,012. Hal tersebut menandakan bahwa variabel OPM tidak berpengaruh terhadap nilai perusahaan. Hal ini berbeda dengan penelitian yang ada sebelumnya Roma (2003) yang menyatakan operating profit margin memilki pengaruh terhadap nilai perusahaan.

Secara teori, semakin tinggi OPM menunjukkan semakin efisiensi perusahaan mengelola biaya operasi dan semakin efektif meningkatkan tingkat penjualannya. Jika OPM semakin tinggi menunjukkan kinerja perusahaan semakin baik, dan pada akhirnya berdampak pada kenaikkan harga saham di pasar modal dan tentu akan meningkatkan pula nilai perusahaan tersebut.

\section{Pengaruh Net Profit Margin (NPM) terhadap Nilai Perusahaan}

Net Profit Margin yang tinggi menandakan adanya kemampuan perusahaan yang tinggi untuk menghasilkan laba bersih pada pendapatan tertentu begitu juga sebaliknya. Net Profit Margin menunjukkan kemampuan bank untuk menghasilkan laba bersih yang memiliki hubungan dengan 
pendapatan perusahaan yang akan datang, yang nantinya akan bermanfaat dalam memprediksi pertumbuhan laba bagi perbankan. Hal ini tentu berdampak peningkatan nilai perusahaan.

Hasil pengujian mengenai pengaruh net profit margin terhadap nilai perusahaan menunjukkan hasil nilai t sebesar 2.159 dengan signifikansi sebesar 0,034. Nilai t hitung yang lebih kecil dari t tabel 2,00030 tersebut menandakan bahwa variabel net profit margin tidak berpengaruh terhadap nilai perusahaan. Hasil penelitian ini mendukung dengan penelitian yang ada sebelumnya Rinati (2009) yang mengemukakan hasil bahwa net profit margin tidak berpengaruh terhadap nilai perusahaan. Dimana menunjukkan bahwa semakin tinggi laba bersih perusahaan maka semakin tinggi nilai perusahaannya.

\section{Pengaruh Corporate Social Responsibility (CSR) terhadap Nilai Perusahaan}

Secara teori, pengungkapan CSR seharusnya dapat menjadi pertimbangan investor sebelum berinvestasi, karena di dalamnya mengandung informasi sosial yang telah dilakukan perusahaan. Informasi tersebut diharapkan menjadi pertimbangan untuk berinvestasi oleh para investor. Dalam UU perseroan terbatas No 40 tahun 2007, bahwa perusahaan pasti melaksanakan CSR dan mengungkapkannya, karena apabila tidak melaksanakan CSR, maka perusahaan akan terkena sanksi sesuai dengan ketentuan peraturan perundang-undangan sehingga dianggap pengungkapan CSR tidak memberi pengaruh terhadap nilai perusahaan.

Hasil pengujian diketahui pengaruh pengungkapan CSR terhadap nilai perusahaan menunjukkan hasil nilai t sebesar -1.538 dengan signifikansi sebesar 0,129 . Nilai signifikansi yang lebih besar dari 0,05 tersebut menandakan bahwa pengungkapan CSR tidak mempengaruhi secara signifikan terhadap nilai perusahaan. Hal ini menunjukkan bahwa investor tidak merespon atas pengungkapan CSR yang telah dilakukan oleh perusahaan. Hasil penelitian ini berbeda dengan penelitian yang ada sebelumnya Yuniasih dan Wirakusuma (2007) yang mengemukakan hasil bahwa pengungkapan corporate social responsibility berpengaruh terhadap nilai perusahaan. Dimana semakin tinggi tingkat pengungkapan CSR mengakibatkan peningkatan nilai perusahaan. Dan juga pada hasil penelitian yang dikemukakan oleh Chairul Amri (2011) yang mengemukakan bahwa CSR berpengaruh secara signifikan terhadap nilai perusahaan.

Tetapi penelitian ini sejalan dengan penelitian yang ada sebelumnya Wahyu Ardimas (2010) yang mengemukakan hasil bahwa pengungkapan CSR tidak berpengaruh secara signifikan terhadap nilai perusahaan. Dan juga pada penelitian yang dikemukakan oleh Angra Hermawati (2010) yang mengemukakan bahwa CSR berpengaruh signifikan terhadap nilai perusahaan.

\section{Kesimpulan}

\section{PENUTUP}

Berdasarkan hasil analisis dan pembahasan yang telah telah dilakukan pada bab sebelumnya, maka diperoleh kesimpulan sebagai berikut.

1. Variabel kinerja keuangan yang diukur dengan return on assets (ROA) dan return on equity (ROE) mempunyai pengaruh secara signifikan terhadap nilai perusahaan. Sedangkan variabel kinerja keuangan lainya, yaitu operating profit margin (OPM), dan net profit margin (NPM) tidak mempunyai pengaruh secara signifikan terhadap nilai perusahaan pada perusahaan Manufaktur di Bursa Efek Indonesia.

2. Variabel corporate social responsibility (CSR) tidak mempunyai pengaruh secara signifikan terhadap nilai perusahaan pada perusahaan Manufaktur di Bursa Efek Indonesia. Hal ini dikarenakan investor tidak merespon atas pengungkapan CSR yang telah dilakukan oleh perusahaan.

3. Dari hasil pengujian yang dilakukan secara simultan (bersama-sama) menunjukkan bahwa return on asset, return on equity, operating profit margin, net profit margin, dan corporate social responsibility mempunyai pengaruh terhadap nilai perusahaan yang diproksikan price to book value (PBV) pada perusahaan Manufaktur di Bursa Efek Indonesia. 


\section{Saran}

Berdasarkan hasil penelitian serta hal-hal yang terkait dengan keterbatasan penelitian, maka terdapat beberapa hal yang perlu diperhatikan, yaitu. Bagi investor dan calon investor perusahaan yang terdaftar di Bursa Efek Indonesia agar lebih seksama dan juga memperhatikan aspek Corporate Social Responsibility perusahaan sebagai pertimbangan dalam melakukan investasi. Setiap perusahaan hendaknya terus meningkatkan kualitas dan kuantitas pengungkapan karena tingkat pengungkapan CSR pada perusahaan manufaktur yang terdaftar di BEI masih sangat rendah dan belum mengikuti standar yang dikeluarkan regulator. Bagi peneliti selanjutnya, diharapkan menggunakan rasio keuangan perusahaan yang berbeda, yang belum dimasukkan dalam model penelitian ini. Karena masih terdapat rasio keuangan yang mungkin juga berpengaruh terhadap nilai perusahaan selain return on asset (ROA), return on equity (ROE), operating profit margin (OPM), dan net profit magin (NPM). Penelitian selanjutnya diharapkan dapat menggunakkan periode penelitian yang lebih panjang dengan tujuan untuk memperoleh hasil yang lebih baik.

\section{DAFTAR PUSTAKA}

Brigham, F. E, dan Houston, F. J. (2006). Dasar-dasar Manajemen Keuangan. Buku 1. Edisi 10. Jakarta: Salemba Empat.

Ghozali dan Chariri, 2007. Teori Akuntansi. Semarang: Badan Penerbit Undip.

Ghozali, Imam. 2006. Analisis Multivariate dengan Program SPSS. Edisi Ke 4. Badan Penerbit Universitas Diponegoro. Semarang.

Haruman, Tendi. 2008. Pengaruh Struktur Kepemilikan Terhadap Keputusan Keuangan dan Nilai Perusahaan. Simposium Nasional Akuntansi XI, Pontianak

Munawir. 2010. Analisis Laporan Keuangan, Edisi 4, Liberty, Yogyakarta.

Rahayu, Sri. 2010. Pengaruh Kinerja Keuangan Terhadap Nilai Perusahaan dengan Terhadap Nilai Perusahaan Dengan Pengungkapan Corporate Social Responsibility dan Good Corporate Governance Sebagai Variabel Pemoderasi. Skripsi Fakultas Ekonomi. Universitas Udayana. Denpasar.

Salvatore, Dominick. 2005. Ekonomi Manajerial dalam Perekonomian Global. Salemba Empat: Jakarta.

Zuredah, Isnaeni Ken. 2010. Pengaruh Kinerja Keuangan Terhadap Nilai PerusahaanDengan Pengungkapan Corporate Social Responsibility Sebagai Variabel Pemoderasi.Skripsi Fakultas Ekonomi. Universitas Pembangunan Nasional. Jakarta.

Handoko, Yuanita, 2010. Pengaruh kinerja keuangan terhadap nilai perusahaan dengan pengungkapan Corporate Social Responsibility dan Good Corporate Governance sebagai Variabel Pemoderasi. Jurnal Akuntansi, hal 1-15.

Nurlela, Rika dan Islahudin. 2008. Pengaruh Corporate Social Responsibility terhadap Nilai Perusahaan dengan Prosentase Kepemilikan Manajemen sebagai Variabel Moderating. Simposium Nasional Akuntansi XI. Pontianak.

Sutrisno. 2008. Manajemen Keuangan Teori, Konsep dan Aplikasi. Yogyakarta. Terdaftar di BEI. Skripsi Universitas Gunadarma. Depok.

Kasmir. 2012. Analisis Laporan Keuangan, PT. Raja Grafindo Persada, Jakarta.

Gitman, Lawrence J. dan Chad J. Zutter. 2012. Principles of Managerial Finance : Brief. Edisi keenam. Boston: Pearson Education.

Amri, Chairul. 2011. Analisis Pengaruh Kinerja Keuangan, Good Corporate Governance dan Corporate Social Responsibility Terhadap Nilai Perusahaan. Skripsi Fakultas Ekonomi. Universitas Gunadarma. Depok.

Hermawati, Angra. 2010. Pengaruh Kinerja Keuangan Terhadap Nilai Perusahaan

Sugiyono. 2011. Metode Penelitian Kuantitatif, kualitatif dan $R \& D$. Alfabeta, Bandung. 